\title{
Port Pricing in the North Port of Split: A Comparative Analysis
}

\author{
Luka Vukić, Ivan Peronja, Merica Slišković
}

Pricing in ports is an important element of port competitiveness when it comes to the establishment of logistics and transportation systems, determining cargo flows, and developing optimum and quality service. This paper aims to examine the need to modify the port tariff in the North Port of Split through comparison of the tariff system in the main Croatian cargo ports for specific vessel categories and types of cargo. The results were also compared with the port tariffs in the ports of Koper and Trieste to identify shortcomings and suggest potential modifications of individual service prices. The analysis revealed a discrepancy in the segment of port charges, towage and light dues (which account for almost $75 \%$ of the total price), with the latter indicated as a crucial problem in all Croatian ports. Tariff adjustment would eventually improve port competitiveness, with the possibility of expansion to new markets, extension of the gravitational area, and acquisition of additional cargo for the North Port. The inclusion of "environmental charge", with envisaged discounts or additional charges for environmental protection and sustainable development, is essential for the port's strategic orientation and market positioning.

\section{KEY WORDS}

$\sim$ Competitiveness

$\sim$ Pricing

$\sim$ Port of Split

$\sim$ Sustainable development

$\sim$ Tariffs

\section{INTRODUCTION}

At the moment, ninety percent of world trade is carried by sea, making ports an indispensable part of the world's economic system. The development of an integrated and sustainable transportation system is inconceivable without ports and the port industry. The high quality of port services, including the optimum price of such services, is an indicator of competitive advantage of ports on a specific transportation route. Among economic criteria, a port's pricing model and tariff policy are some of the dominant if not decisive items influencing ship operator's choice of transportation route and the most suitable port for cargo operations. Since cargo flows are changing rapidly, the objective of the port management and other participants, apart from investments into port infrastructure and services, is to establish a competitive, optimum and attractive pricing system ensuring the acquisition of new cargo.

This paper presents the port tariff systems in the main cargo ports in the Republic of Croatia (Rijeka, Ploče and Split), giving an overview of the complexity of the pricing system and market players involved, with the focus on the cargo Port of Split (North Port). These three ports account for almost $90 \%$ of total freight in Croatia and are positioned as important transit ports for Eastern and Central European markets. Since the tariff system in Croatia differs from port to port, the differences need to be analyzed. An analysis of three observed vessels carrying different cargo into ports has been conducted to emphasize the competitive advantage of each port, with focus on the North Port, identify the shortcomings and suggest potential modifications of the tariff system. All entities operating in the port area are required to adjust their business plans and pricing models to increase cargo turnover in the North Port.

\section{ROLE AND SIGNIFICANCE OF PORT PRICING}

Seaports are an essential element of supply chains and distribution channels, especially those related to international 
trade (Strandenes and Marlow, 2000). Ports are generators of trade (Valantasis-Kanellos and Song, 2015) and their integration into the global economic system is more important and significant than ever before (Dwarakish and Salim, 2015; Berköz and Tekba, 1999), considering that over $90 \%$ of the world trade is carried by sea (IMO, 2017). Ports and the port industry are vital for the development of an integrated and sustainable transportation system, bearing in mind that ports are the centers of economic and industrial activities (Virlanuta et al., 2013) essential for the functioning of the transportation process and transportation services (Jugović, 2012). Pricing by ports and operators within the ports is historically determined (Meersman et al., 2003). Since the purpose of pricing is to stimulate the development and diversification of various services for all beneficiaries with both quality improvement and increased service performance efficiency, the prices and pricing systems are an important aspect of any economy (Virlanuta et al., 2013). When it comes to ports and the implementation of pricing into their strategic plans, pricing is a major factor (UNCTAD, 1995). Depending on market orientation, supply and demand ratio, the intensity and nature of competition, pricing is a contributing factor of company competitiveness (Virlanuta et al., 2013). Given the fact that ports are multi-output enterprises, with the main activity of commercial ports being defined as a chain of interlinked services (Meersman et al., 2010), these services are charged individually and by different parties (Acciaro, 2013). The cost incurred by a port entity needs to be covered through port charges (UNCTAD, 1975). Fees charged by the port authority are port tariffs for facilities and port dues (UNCTAD, 1995). Port services provided by other port entities or operators are the physical assets of the port facilities, such as pilotage, cargo handling etc. Commercial activities are most frequently performed by the private sector and often give rise to competition (UNCTAD, 1975). Pricing in ports is therefore strongly influenced by the structure of the maritime industry and the bargaining power of industry participants (Mchizwa, 2014).

A sizeable number of market players are involved in the creation of the port product value chain, defined as a chain of consecutive links (Suykens and Van de Voorde, 1998). Since the coordination of business activities is an important segment of the overall supply chain, the collaboration between various entities in the port business is essential for a more efficient economy. Various activities in the port, like infrastructure services are mainly provided by port authorities, with cargo handling and other services such as mooring, pilotage, etc. being provided by private enterprises (Dwarakish and Salim, 2015). Third parties like pilots, waste disposal facilities and bunkering companies, towage services, ship repairs and provisioning provide services indispensable for the operation of shipping companies (Meersman et al., 2014).

The demand for goods, requisite for economic growth, industrial production and international trade, is an indicator defined as demand for port calls, port transshipment and supplementary services, and in this sense pricing by and within ports is an important factor (Meersman et al., 2003). Ports play a significant role in the global supply chain as trade facilitators, where pricing is of interest to both academic and business entities (Acciaro, 2013).

Pricing by and within ports should correspond to the costs generated by ships (Meersman et al., 2003). With the growing global trend in the maritime sector and shipbuilding and changes in the demand for cargo and port services, digitalization and sustainability, port's competitiveness and market position can be ensured by the modernization of port services and port infrastructure. The acquisition of new cargo also depends on the quality of the tariff system and transportation service, having either stimulating or destimulating effect on cargo acquisition (Jurjević et al., 2016). Many factors influence the valuation and competitiveness of the transportation route, like geographical position, transportation corridors, transportation flows, transport infrastructure and superstructure, catchment area, competition, transport policy and tariff policy (Jurjević et al., 2016). Economic criteria (price of service) can be concluded to play an essential role in port competitiveness, as well as its attractiveness for cargo and the volume of port traffic. Economic criteria are, apart from qualitative criteria, the main factors of transportation route competitiveness and include port costs and land transportation costs (Poletan Jugović, 2006). These port costs are port charges and consist of: light dues, port dues, pilotage, mooring/unmooring, customs clearance, agency fee, waste disposal, license fee, bank guarantee, towage and miscellaneous (Dundović and Hess, 2005).

\section{CURRENT PORT PRICING MODELS}

The paper by Acciaro (2013) gives a review of the port pricing literature with various port pricing approaches proposed by authors of the documents. He concludes that the literature is structured around five main themes: strategic pricing, pricing and market conditions, pricing and infrastructure cost recovery, pricing and external costs and empirical studies. Each author has his own approach to the complexity of port pricing whether it is the congestion model of pricing, marginal cost pricing or the UNCTAD reports from 1975 and 1995 which considered pricing a strategic issue.

There are two basic port pricing models: economic and financial. The economic approach refers to port pricing based on marginal cost, considering the effect of users on the port, including benefits (UNCTAD, 1975). The marginal costs system is based on the principle that port users should meet the additional costs they impose on the port (Acciaro, 2013), and enjoys support due to its potential to increase economic welfare (Mchizwa, 2014). Meersman et al. (2003) state that port prices 
should be based on short-run marginal costs indicating the precise difference in costs in case of acceptance and refusal of an additional user, while Haralambides et al. (2001) state that longrun marginal costs represent the most useful basis for efficient pricing. In his previous paper (Haralambides, 2000), according to a report by the Academic Expert Group (AEG), states that marginal cost pricing is not as straightforward in ports operating in the competitive environment, whereas full cost recovery, combined with the user pays principle, can form a working basis for fair and efficient pricing. The financial approach is based on accounting costs allowing the port to reclaim fixed and variable costs of providing the facilities and services, while also realizing an adequate return on investment. Simplified, the aim of the financial approach is to generate profit (UNCTAD, 1995). Bearing in mind that most authors state that the inclusion of marginal costs is a prerequisite for efficient port pricing, literature on this approach is rather scant (Haralambides et al., 2001).

The UNCTAD (1995) gives a review of strategic port pricing, a model that can be a very useful tool for achieving the objectives of a port's strategic plan, emphasizing that port charges are related to port objectives.

\section{REFLECTION OF CPV APPROACH IN CROATIAN PORTS}

The most common approaches to port pricing are provided in the UNCTAD (1975 and 1995) documents indicating pricing as a strategic issue, where the first was based on the economic approach focusing on costs, utilization and what traffic can bear, and the other on the three critical elements: cost, performance and value (CPV), with an emphasis on cost-based tariffs for maximizing port services, performance-based tariffs for maximizing throughput and reducing congestion, and valuebased tariffs for generating sufficient revenue to cover port costs. All these elements are incorporated in the term strategic pricing, defined as "the use of pricing as a mechanism for achieving competitive advantage" (UNCTAD, 1995), and indicated as the fundamental part of the implementation of the strategic plan in the port business model. Strategic pricing is based on the principle that cargo and user elasticity in the demand for port services differ depending on prices.

The CPV model offers a wide variety of options for port management to draw up a port policy in the interest of both the port and its users. Furthermore, this approach offers a plethora of options for the allocation of port resources, like limiting pricing by imposing a minimum price or floor limit, where ports are prohibited from charging less than the incremental cost of serving the user and ceiling or maximum limit, forbidding them to charge more than the value received by the user, improving policy and decision flexibility to increase a port's productivity and competitiveness on the market (Meersman et al., 2003).
The CPV approach in the Port of Split is analyzed with the current tariff system in mind. The cost-based pricing is reflected in the recovery of the costs of the port authority and the utilization of facilities and services by users, and divided into fixed, variable and marginal costs depending on cost type (UNCTAD, 1995). An examination of the tariff system in the Port of Split leads us to conclude that the port authority applies cost-based pricing in all tariff system categories, but should strive to improve process efficiency, i.e. cost-based pricing should be reflected, as suggested by UNCTAD (1995), in pilotage, towage, berthing, cargo handling and all other charges, in the framework of both performance and value-based pricing.

Performance-based pricing stresses the importance of efficient and optimum utilization of port assets, taking into consideration both the time of facility usage and user waiting time. The concept is based on the decision to decrease or increase the tariff depending on whether facility utilization is below or above optimum level. The main performance-based pricing charges are berth hire and warehouse charges. Performancebased pricing focuses on increasing the productivity of port operators, anticipated to boost port efficiency and throughput (UNCTAD, 1995). Due to its unenviable market position, the Split Port Authority offers a variety of options in the context of performance-based pricing, like convenience in the extension of the amount of time cargo can be stored in transit warehouses and granting rebates to vessels which commence with cargo operations immediately after berthing, but likewise imposing additional charges or fines for delays. A detailed analysis of the above-mentioned issues should be conducted, since they are dependent upon different influences, like the quality of equipment and operational possibilities in the port, and market conditions.

The objective of value-based pricing is to generate sufficient revenue to cover all costs incurred during service and facility provision, while simultaneously estimating the port users' willingness to pay the requested price. The concept is based on the reaction of port users to price changes, and is known as price elasticity (UNCTAD, 1995). Tariff level changes have an impact on entrepreneurs mainly in the sense of logistical costs and final price of the product. The pricing system policy in the Port of Split needs to be stimulating to keep the existing customers, especially considering the availability of alternative transportation routes concentrated in the ports of Rijeka and Ploče. Bearing in mind the relatively limited market in the gravitational area of the Port of Split and consistent mobility and connectivity issues, mostly due to the condition of railway transportation, the characteristics of user demand should be taken into account when defining charges, in order to allocate benefits and achieve price elasticity. The value-based tariffs are mainly port charges on ships and cargoes (UNCTAD, 1995). These charges are differentiated depending on vessel and cargo types (container, dry bulk, etc.) as is the case in the Port of Split. 


\section{COMPARISON BETWEEN PORT PRICING IN CROATIA AND WORLDWIDE}

Global trends in pricing in ports are very similar to those in Croatia. Basic charges for the use of port services prevail in most countries, varying only in the charge type and terminology. The state, along with port authority and other entities operating in the port area, depending on the port management model, can recommend, based on the principles of sustainable development, the application of a specific charge in its area of jurisdiction. This charge can refer to discounts or additional charges depending on environmental protection, especially air pollution level, the use of older or new technologies (type of fuel), construction of the vessel and other criteria. This "additional" charge aims to ensure competitiveness and stimulate investment into and modernization of port facilities and services, while simultaneously facilitating throughput in congested ports. Likewise, this charge is used by ports with the strategic purpose of being positioned on the market as an "eco-port" or "eco-friendly", with the special care and contribution to the environment, creating a brand and raising the awareness of environmental protection. The environmental component prevails in the calculation of surcharges or discounts on the basic price, and according to the literature and examples worldwide, is expected to become the leading indicator in the future, both for the port management and for shipping companies. The port of Gothenburg is an example of good practice, where environmental discounts are granted to vessels registered in accordance with the CSI (Clean Shipping Index) and ESI (Environmental Ship Index), namely a $10 \%$ discount on port charges, depending on GT (gross tonnage), and a $20 \%$ discount on port charges for vessels to LNG-powered vessels, depending on GT, if LNG is installed (Port of Gothenburg, 2017). The Port of Rotterdam likewise recognizes the importance of improving environmental performance, safety and quality, offering discounts for various scenarios, e.g. having a green award certificate, in the form of $6 \%$ discount on port charges already paid, $10 \%$ discount on port charges dependent upon GT-size already paid, discount on the ESI score of more than 31 points, agribulk discount depending on the number of vessel port calls, second call discount for seagoing vessels in deep-sea service, various transshipment and other discounts (Port of Rotterdam, 2017). The Port of Hamburg introduced a new fee rating system featuring an environmental component, categorically calculated and based on International Air Pollution Prevention (IAPP) certifications, i.e. environmental impact. In practice, vessels without IAPP certificate or with poor emission levels have to pay surcharges on the regular (basic) price, and are granted discounts when rated very clean based on the IAPP certificate (Port of Hamburg, 2017). In the framework of the ECHO program, the Port of Vancouver offers a discount for the protection of mammals (whales) and the prevention of potential threats in the form of acoustic disturbance (underwater noise), physical disturbance (ship collisions), environmental contaminant and others (Port of Vancouver, 2017). Furthermore, in 2017, the Russian Ministry of Transportation introduced special investment charges in national seaports dependent upon the vessel's GT with the aim of investment into construction and development of state-owned facilities in seaports, imposed on all cargo vessels calling in Russian seaports (Port today, 2017). Additional charges can also be imposed on safe passage, like in the Suez or Panama Canals, where vessels are obligated to meet the costs intended to compensate the investment into infrastructure and superstructure to the states having jurisdiction of the area.

As already mentioned in the previous section, these compulsory charges and the charges for the use of port services, are similar in the vast majority of ports, so we can talk about a unique or standardized model of charges, differentiated only by additional charges characteristic of a specific port or area, and business policy based on sustainable development. The initiatives of institutions like BIMCO and FONASBA (BIMCO, 2017) to standardize the format and contents of port charges support this statement and provide useful information both for the ship owners and ship agents.

All these additional charges represent different pricing system options used worldwide, and it can thus be observed that the Croatian pricing system is in line with global trends. The potential possibilities are enormous and manifested by the introduction of additional costs, potentially in the field of environmental protection and sustainability of coastal area, supported by sustainable development strategies at the national and transnational levels.

\section{PORT PRICING IN THE NORTH PORT OF SPLIT}

In the Republic of Croatia, port authorities are public non-profit institutions in $100 \%$ ownership, in charge of the management of Croatian ports (Krčum et al., 2015). Port authorities are tasked with the management, construction and maintenance of the port area, the organization of port services and awarding concessions to port operators providing port services (Jugović, 2012).

Pricing in ports in the Republic of Croatia is a complex system, with maritime logistics and transportation chain being characterized by numerous participants, each striving to operate efficiency and sustainably on the market to raise their profitability and ensure growth. The port tariff system is created and harmonized with the involvement of all stakeholders, to ensure competitive advantage and increase a port's attractiveness for new cargo and markets.

A review of entities involved in the process of vessel arrival and departure in the Port of Split is shown in Figure 1. Indirectly, the figure gives a clear overview of involvement of numerous stakeholders in the transportation chain offering their service in a "user pays" system. 


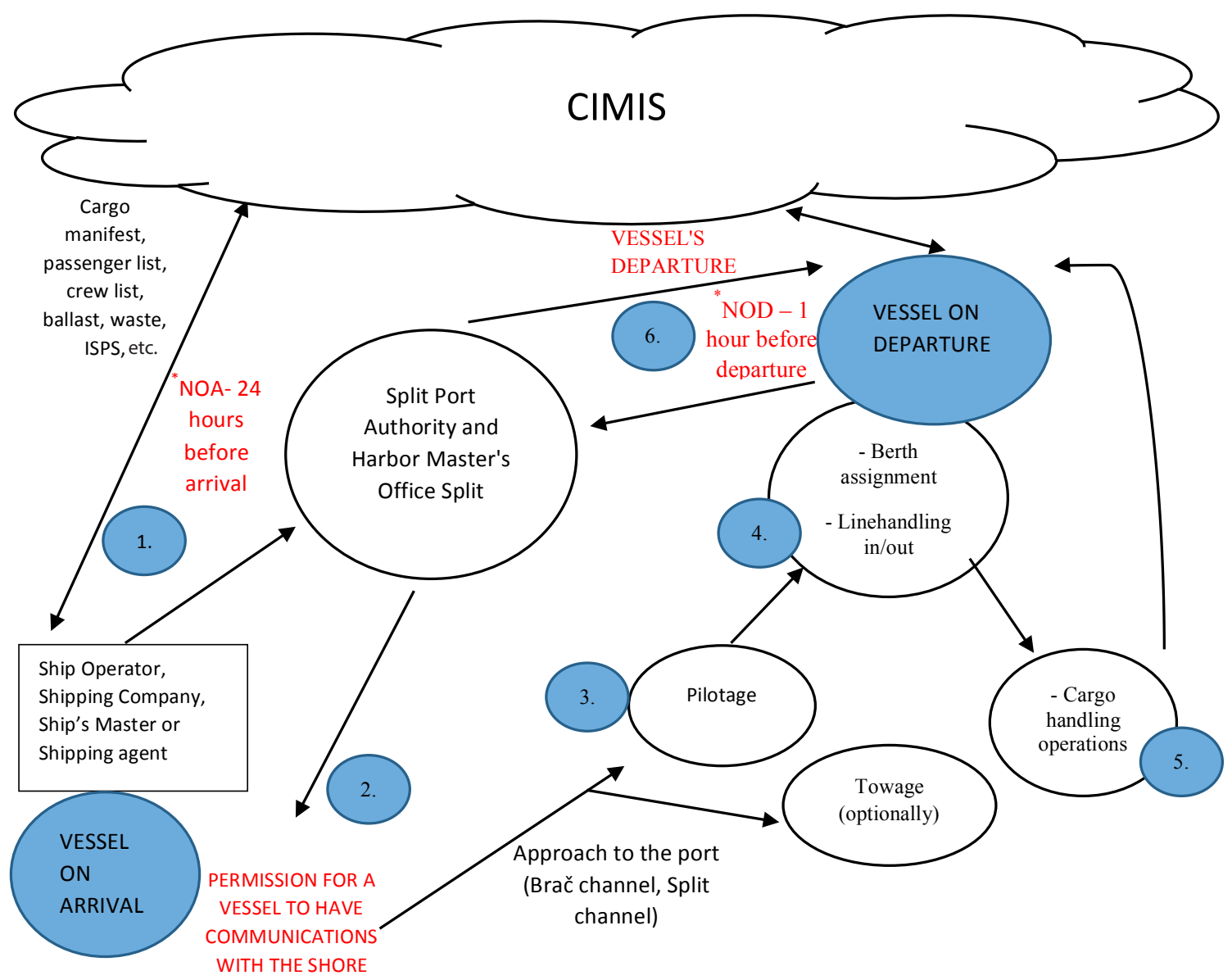

Figure 1.

Entities involved in the vessel arrival/departure procedures in the Port of Split.

All entities participating in this process, apart from the Harbor Master's Office as a constituent part of the Ministry of the Sea, Transport and Infrastructure, are service providers charging their services. It is important for the ship's operator to efficiently coordinate all the necessary procedures to reduce potential waiting time and additional costs. Any vessel planning a call to the Port of Split is obligated to submit the Notice of arrival (NOA) to the Port Authority and the Harbor Master's Office in Split at least 24 hours before arrival. Following the completion of the evaluation process, the Harbor Master's Office issues a permission for the vessel to communicate with the shore, enabling the vessel to continue with its primary operations depending on the nature of the transportation (passenger or cargo). Having obtained the permission, the vessel is obligated to use pilotage services to ensure its safe entrance into port and optionally towage services, at the Harbor Master's discretion. The Port Authority, within its jurisdiction, assigns berths to vessels, while other entities initiate the provision of their own services like line handling operations, cargo handling operation, waste management, etc. Following the completion of necessary operations in the port of call, on departure, the vessel is obligated to submit Notice of departure (NOD) to the Port Authority and the Harbor Master's Office which, after the completion of the evaluation process, issues the permit for the vessel's departure. It is important to emphasize that all the required documents (passenger list, crew list, waste, ballast water, etc.) have to be entered into the Croatian integrated information system (CIMIS) facilitating the administration process and database creation.

Since the tariff model in the Republic of Croatia is not unified, each port, governed by the port authority, is responsible for its tariff system and defining port prices relying on different indicators like the quantity of traffic or market condition, feedback from port users and operators, third party service providers, etc. The aim of the port authority, as a public non-profit institution, is to recover its investments, and collect all revenue from the use of facilities and services in the form of concessions and port 
charges which is then reinvested into port infrastructure and superstructure as well as into the improvement of port services, modernization and maintenance of the port area to achieve competitive advantage in the Adriatic and its gravitational area of interest. So, the Croatian and Port of Split's tariff systems can be concluded to be based on four principles: competitiveness, cost recovery, required revenue and the "user pays" principle. The individual items are shown in Table 1.

Table 1.

Port service charges in the Port of Split.

\begin{tabular}{|c|c|c|c|c|}
\hline ACTIVITY & SERVICE & SERVICE PROVIDER & $\begin{array}{l}\text { SERVICE } \\
\text { USER/PAYER }\end{array}$ & CHARGING UNIT \\
\hline \multicolumn{5}{|l|}{ 1. PORT SERVICES } \\
\hline Launching & clearance at anchorage & Private company & Shipping line & - GT (gross tonnage) \\
\hline Pilotage & $\begin{array}{l}\text { assistance for vessels } \\
\text { entering/leaving port }\end{array}$ & $\begin{array}{l}\text { Private company } \\
\text { (Pomorski peljar d.o.o.) }\end{array}$ & Shipping line & $\begin{array}{l}\text { - basic tariffs based on GT } \\
\text { (gross tonnage) }\end{array}$ \\
\hline Towage & $\begin{array}{l}\text { assistance to vessels } \\
\text { entering/leaving port }\end{array}$ & $\begin{array}{l}\text { Private company } \\
\text { (Brodospas d.d.) }\end{array}$ & $\begin{array}{l}\text { Shipping line - } \\
\text { optional }\end{array}$ & $\begin{array}{l}\text { - per service (hour), based } \\
\text { on GT (gross tonnage) }\end{array}$ \\
\hline Berthing services & $\begin{array}{l}\text { services to tie/untie vessels } \\
\text { at berth }\end{array}$ & $\begin{array}{l}\text { Private company } \\
\text { (Legio Quarta) }\end{array}$ & Shipping line & - GT (gross tonnage) \\
\hline \multirow[t]{4}{*}{ Port dues } & demurrage & \multirow[t]{4}{*}{ Split Port Authority } & \multirow[t]{4}{*}{ Shipping line } & \multirow{2}{*}{$\begin{array}{l}\text { - by day (whole day) and } \\
\text { vessel length }(\mathrm{m})\end{array}$} \\
\hline & berthing fee & & & \\
\hline & \multirow{2}{*}{ wharfage } & & & - vessel length (m) \\
\hline & & & & $\begin{array}{l}\text { - loaded/unloaded ton of } \\
\text { cargo } \\
\text { - embarked/disembarked } \\
\text { passenger/vehicle }\end{array}$ \\
\hline Port fees & $\begin{array}{l}\text { services for port users (soft } \\
\text { and liquid waste disposal, } \\
\text { cargo loading and unloading, } \\
\text { warehouse storage etc..) }\end{array}$ & Port concessionaires & Shipping line & - per service (various) \\
\hline
\end{tabular}

\section{DUES AND TAXES}

Light dues the use of navigation safety facilities in Croatia

clearance on arrival/ departure

each vessel calling to

Croatian port
Government (Plovput d.o.o.)

Government

Government

(Immigration

permits, ISPS, ASBAC

fee etc.)

\section{AGENCY CHARGES AND EXPENSES}

\section{Agency costs}

Other expenses (car for authorities, bank charges, telecomm. / miscellaneous etc.) agency fee for user services Shipping agents

various
Various
- unit measurement for all vessels is GT (gross tonnage)

Shipping line flat rate (different for vessels performing the commercial and noncommercial operations) per service per service (flat rate)

Shipping line 
The pricing system in the Port of Split, is based on Port Authority's charges in the form of port dues and charges imposed by concessionaires providing services to port users in the form of port fees. Port dues are divided into three segments: wharfage, demurrage, and berthing charges, and represent the revenue of the Split Port Authority. Wharfage dues are paid by vessels using the port for embarkation or disembarkation of passengers, vehicles, and cargo loading/unloading. The unit of measurement for wharfage dues calculation is loaded/unloaded ton of cargo (whole tones only) and embarked/disembarked passenger or vehicle. For cruisers, the unit of measurement is gross tonnage and charges depend on the number of passengers and crew. Demurrage is paid by ships staying in ports for any purpose other than embarkation or disembarkation of passengers, and/ or loading/unloading of cargo. The units of measurement for demurrage dues are day (whole day only) and vessel length in meters $(m)$. Berthing dues are paid by the owners of fishing ships, yachts, fishing and sports boats, other types of boats and floating objects (Split Port Authority, 2017).

Port fees are charged for services provided by port concessionaries operating in the port area. In publicly open ports like the Port of Split, concessionaires are obligated to publicly announce the fees for each particular activity or service. These fees include charges like fumigation, deratization, control and quality of goods, solid and liquid waste disposal, mooring and unmooring of vessels, yachts, fishing and sports boats, other types of boats and floating objects, water and electricity supply, cargo loading and unloading, warehouse storage and others.

To achieve and maintain the port's competitiveness, the port authority may modify its tariffs (port dues) and offer a wide variety of discounts for a number of ships' ports of call, like in the case of the Port of Split, in order to adapt its business to increasing market demand. Usually, they negotiate with longtime customers, and customers having long-term agreements and contracts (Jurjević et al., 2016). It is essential for the Split Port Authority to establish a favorable relationship and communication with the concessionaires having discretion in the creation of their own tariffs (fees). It is important for the port's progress, development and competitiveness, for all entities in the port area to harmonize their business strategies and invest in the port facilities and services to attract more vessels and cargo.

Vessels entering the Port of Split are obligated to pay "compulsory charges". These charges are imposed on every vessel regardless of the nature of mobility or type of cargo. The first is the light fee or fee for the use of navigation safety facilities, which is paid depending on gross tonnage (GT) or vessel type on the monthly or yearly basis, depending on the number of the vessel's ports of call. This charge is obligatory for every vessel entering the Republic of Croatia. Other charges are port charges as mentioned above, divided into quay dues, wharfage and berthage charged depending on the type of the vessel, pilotage, mooring/unmooring services, administration costs, agency fees and others. In some cases, mainly in the case of bad weather conditions at sea and depending on the agreement of the pilot and the ship's captain, the vessel may use the services of a towage company.

\section{COMPARISON OF PORT TARIFFS IN THE MAIN CROATIAN CARGO PORTS}

The analysis of the tariff systems in the main Croatian cargo ports of Rijeka, Ploče, and Split based on vessel type and type of cargo, is provided according to the model made by Jurjević et al. (2016), with some deviations. Here is the analysis of three vessels, carrying different cargo, indicating pricing policy methods and differences and emphasizing competitive advantage of each specific port with focus on the North Port (Port of Split). In order to improve port competitiveness and attract more cargo, shortcomings are identified and potential modifications of the tariff system proposed. Since these three ports account for almost $90 \%$ of the total freight transportation in all Croatian ports (Ministry of the Sea, 2017), the analysis is necessary for the evaluation of the current state of pricing in ports, especially in the Port of Split.

The analysis is based on port charges for vessels performing commercial activities within the port area. Each service is charged in compliance with existing regulations, so that the total price is the sum of port tariffs for each individual vessel obligated to compensate the use of port activities and structures. All prices also contain a projection of overtime (additional) work required to perform the activities and are increased depending on requirements and conditions in the port (e.g. number and working hours of tugboats) and, for the purpose of this paper, based on publicly available tariffs and the experience of port agents in the determination of prices for each individual vessel. The comparison of the tariff systems used in main Croatian cargo ports is provided in Table 2. Individual tariffs, taken for the purpose of this analysis, are publicly announced for each particular activity or service and are not completely reliable in this form since they do not account for direct negotiations between service providers and customers mainly resulting in lower rates granted on the basis of long-term agreements and market conditions. Likewise, it has to be noted that vessel and cargo types have been chosen only to indicate the fluctuation of port charges, without taking into consideration the actual limitations in main Croatian ports with respect to vessel length and draft. In reality, the third vessel unloading $80.000 \mathrm{MT}$ of coal would be unable to enter the ports considered in this analysis, due to the draft of $15 \mathrm{~m}$, considering the limitation of vessel draft in the Port of Ploče to $13.8 \mathrm{~m}$, Split to $10.2 \mathrm{~m}$ and Rijeka to $11.8 \mathrm{~m}$ (Dundović et al., 2012). However, the obtained data are clearly indicative of the situation, as intended by this analysis, primarily in the port tariff system. The analysis 
Table 2.

Port charges for general cargo vessel (1), bulk (grain) (2) and bulk (coal) carrier (3) in the ports of Split, Rijeka, and Ploče (€).

\begin{tabular}{|c|c|c|c|c|c|c|c|}
\hline \multirow[t]{2}{*}{ Cost-type } & Port & \multirow[t]{2}{*}{ SPLIT } & \multirow[t]{2}{*}{$\%$} & \multirow[t]{2}{*}{ RIJEKA } & \multirow[t]{2}{*}{$\%$} & \multirow[t]{2}{*}{ PLOČE } & \multirow[t]{2}{*}{$\%$} \\
\hline & Vessel & & & & & & \\
\hline \multirow[t]{3}{*}{ launch boat } & 1 & 202.50 & 2,6 & 202.50 & 2,9 & 202.50 & 2,4 \\
\hline & 2 & 202.50 & 0,6 & 202.50 & 0,8 & 202.50 & 0,5 \\
\hline & 3 & 202.50 & 0,3 & 202.50 & 0,3 & 202.50 & 0,3 \\
\hline \multirow[t]{3}{*}{ pilotage } & 1 & 352.50 & 4,5 & 352.50 & 5,0 & 352.50 & 4,2 \\
\hline & 2 & $1,307.50$ & 4,2 & $1,307.50$ & 5,0 & $1,432.50$ & 3,5 \\
\hline & 3 & $2,762.50$ & 4,1 & $2,762.50$ & 4,4 & $2,887.50$ & 3,6 \\
\hline \multirow[t]{3}{*}{ towage } & 1 & $1,006.88$ & 12,8 & 661.71 & 9,4 & $1,006.88$ & 11,9 \\
\hline & 2 & $5,219.50$ & 16,6 & $3,440.84$ & 13,3 & $3,814.25$ & 9,2 \\
\hline & 3 & $15,882.81$ & 23,5 & $8,244.43$ & 13,1 & $15,882.81$ & 20,0 \\
\hline \multirow[t]{3}{*}{ line handling } & 1 & 69.75 & 0,9 & 245.63 & 3,5 & 337.50 & 4,0 \\
\hline & 2 & 261.00 & 0,8 & $1,415.25$ & 5,5 & $1,334.50$ & 3,2 \\
\hline & 3 & 629.10 & 0,9 & $3,442.73$ & 5,5 & $3,244.50$ & 4,1 \\
\hline \multirow[t]{3}{*}{ port charges } & 1 & $3,000.00$ & 38,1 & $2,310.00$ & 33,0 & $3,270.00$ & 38,7 \\
\hline & 2 & $13,500.00$ & 42,9 & $8,640.00$ & 33,3 & $23,490.00$ & 56,9 \\
\hline & 3 & $26,400.00$ & 39,0 & $26,400.00$ & 42,0 & $35,200.00$ & 44,4 \\
\hline \multirow{3}{*}{$\begin{array}{l}\text { light dues } \\
\text { (valid for } 30 \\
\text { days) }\end{array}$} & 1 & $1,497.12$ & 19,0 & $1,497.12$ & 21,4 & $1,497.12$ & 17,7 \\
\hline & 2 & $7,764.34$ & 24,7 & $7,764.34$ & 29,9 & $7,764.34$ & 18,8 \\
\hline & 3 & $16,612.46$ & 24,5 & $16,612.46$ & 26,4 & $16,612.46$ & 20,9 \\
\hline \multirow{3}{*}{$\begin{array}{l}\text { customs } \\
\text { charges }\end{array}$} & 1 & 300.00 & 3,8 & 300.00 & 4,3 & 300.00 & 3,6 \\
\hline & 2 & 350.00 & 1,1 & 350.00 & 1,3 & 350.00 & 0,9 \\
\hline & 3 & 350.00 & 0,5 & 350.00 & 0,6 & 350.00 & 0,4 \\
\hline \multirow{3}{*}{$\begin{array}{l}\text { immigration } \\
\text { permits, } \\
\text { ISPS, ASBAC }\end{array}$} & 1 & 195.00 & 2,5 & 195.00 & 2,8 & 195.00 & 2,3 \\
\hline & 2 & 195.00 & 0,6 & 195.00 & 0,8 & 195.00 & 0,5 \\
\hline & 3 & 195.00 & 0,3 & 195.00 & 0,3 & 195.00 & 0,3 \\
\hline \multirow[t]{3}{*}{ agency fee } & 1 & $1,000.00$ & 12,7 & $1,000.00$ & 14,3 & $1,000.00$ & 11,9 \\
\hline & 2 & $2,200.00$ & 7,0 & $2,200.00$ & 8,5 & $2,200.00$ & 5,3 \\
\hline & 3 & $4,000.00$ & 5,9 & $4,000.00$ & 6,4 & $4,000.00$ & 5,0 \\
\hline \multirow[t]{3}{*}{ waste disposal } & 1 & 116.00 & 1,5 & 124.00 & 1,8 & 150.00 & 1,8 \\
\hline & 2 & 116.00 & 0,4 & 124.00 & 0,5 & 150.00 & 0,4 \\
\hline & 3 & 116.00 & 0,2 & 124.00 & 0,2 & 150.00 & 0,2 \\
\hline \multirow{3}{*}{$\begin{array}{l}\text { bank } \\
\text { charges }(0,6 \%)\end{array}$} & 1 & 46.92 & 0,6 & 41.81 & 0,6 & 50.35 & 0,6 \\
\hline & 2 & 187.51 & 0,6 & 154.65 & 0,6 & 246.41 & 0,6 \\
\hline & 3 & 403.92 & 0,6 & 374.90 & 0,6 & 473.37 & 0,6 \\
\hline \multirow[t]{3}{*}{ others } & 1 & 80.00 & 1,0 & 80.00 & 1,1 & 80.00 & 1,0 \\
\hline & 2 & 135.00 & 0,4 & 135.00 & 0,5 & 135.00 & 0,3 \\
\hline & 3 & 170.00 & 0,3 & 170.00 & 0,3 & 170.00 & 0,2 \\
\hline \multirow{3}{*}{$\begin{array}{l}\text { TOTAL } \\
(€)\end{array}$} & 1 & $7,866.67$ & 100 & $7,010.27$ & 100 & $8,441.85$ & 100 \\
\hline & 2 & $31,438.35$ & 100 & $25,929.08$ & 100 & $41,314.50$ & 100 \\
\hline & 3 & $67,724.29$ & 100 & $63,858.52$ & 100 & $79,368.14$ & 100 \\
\hline
\end{tabular}


was conducted for the following categories of vessels and types of cargo, for services in the ports of Split, Rijeka, and Ploče:

- general cargo vessel discharging 3,000 tons $\mathrm{MT}^{1}$ of certain general cargo composition (coils). Vessel's features - $\mathrm{GT}^{2}$ : 3,119; DWT $^{3}$ : 3.500; LOA $^{4}(\mathrm{~m}): 88.00 ; \mathrm{Dft}^{5}(\mathrm{~m}): 5.80$

bulk carrier discharging 27,000 tons (MT) of grain. Vessel's features - GT: 17,973; DWT: 28,000; LOA (m): 165.00; Dft (m): 10.00 - bulk carrier discharging 80,000 tons (MT) of coal. Vessel's features - GT: 47,717; DWT: 80,300; LOA (m): 229.00; Dft (m): 15.00.

The analysis of three categories of vessels carrying different cargo demonstrates a significant fluctuation of port charges in the main Croatian ports. According to the results of the analysis, the Port of Rijeka is in more favorable position and more competitive, offering lowest overall port charges for services in the port area for the general cargo carrier, grain bulk carrier and coal bulk carrier, judging by vessels chosen for this analysis. It is followed by the Port of Split (North Port) and the Port of Ploče as the port with the highest total price for each vessel. Whilst the discrepancy for the general cargo carrier is the lowest, notable difference can be found in the case of grain bulk vessel and coal bulk vessel. The collected data suggest that over $50 \%$ of the total price of port charges for vessels considered in this analysis pertains to port charges and light dues, which are slightly lower in the Port of Rijeka. Larger differences can be found in almost every segment of overall port tariffs. Line handling charges are lowest in the Port of Split. The discrepancy between these charges evidently increases with vessel size, up to four and five times in magnitude among the ports considered. It has to be noted that the calculation of these charges isn't unique and standardized in Croatian ports. Prices for towage services, an optional service for vessels calling into Croatian ports, are slightly lower in Rijeka, charges for pilotage services are similar, as are other charges considered for the purpose of this analysis, like solid waste disposal charges or charge for the launch boat as a control for a vessel at anchorage.

In general, the differences between port tariff systems in Croatian ports depend on several factors. Firstly, the legacy from the past, the elements of port tariffs once created are retained regardless of the changes in fee level or changes to cargo structure and type. Secondly, the difference in the structure of cargo in ports results in the absence of certain categories of cargo and cargo with no relevance, including of corresponding specific fees, while other ports realize turnover from specific types of cargo, and impose specific or specially differentiated fees introduced in line with the business policy of individual port

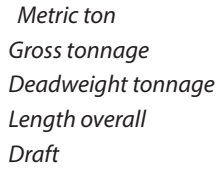

authorities (an effort to attract or stimulate certain types of traffic into a particular port).

Port authorities, apart from support at the highest, strategic levels in Croatia, should obviously consider elements other than port charges, imposed on vessels calling in ports of national interest. This applies not only to the prices of mooring and unmooring (also water and electricity supply, waste disposal, etc.) but especially to light dues, towage and pilotage charges. Light dues for cargo vessels rarely calling at Croatian ports (light dues vary from monthly to yearly with specific indexes multiplied by the vessel's GT) are obviously the most significant constituents of the overall price of port call where they account for a disproportionately large segment of total costs (in this paper more than $20 \%$ of the final price), and should thus be taken into account in the future plans for the modernization and modification of the tariff system.

\section{COMPARISON OF PORT TARIFFS IN CROATIAN PORTS AND THE PORTS OF KOPER AND TRIESTE}

The comparison of results of this analysis presented in Table 3 provides an overview of the current state in the segment of port tariffs in the main Croatian ports and the ports of Koper and Trieste.

This comparison is conducted under the premise that the overall price charged at the port of call is the decisive element of competitiveness, neglecting the actual size of the port and its capacity to accept cargo. The results of the comparison are unfavorable for all Croatian ports, which have almost two to three times higher total costs. The difference is present in almost every segment of port tariffs, especially in the segment of light dues, with the ports of Koper and Trieste, apart from their geostrategic location, modernized port mechanization and facilities and road and railway connectivity, also having competitive advantage in the segment of the overall price of services in comparison with Croatian ports. Likewise, the overall price for the third vessel carrying coal, regardless of the modified and lower vessel specifications (vessel GT, taken into account in case of Croatian ports, is two times lower than in Koper and Trieste, and the volume of discharged cargo lower by one third), points to a large discrepancy between the observed ports and their tariffs, making the Koper and Trieste transportation route more competitive and favorable than Croatian ports. The presented results suggest that the current tariff models used in Croatian ports have to be modified to become more favorable for vessels and cargo owners, which will in turn result in increased cargo turnover and raise competitiveness in the Adriatic. If the mechanism of lower overall price is employed, the potential for exploiting new markets and changing traffic flows, given the same quality of service, is considerable and realistic. 
Table 3.

Comparison of port tariffs in main Croatian ports and the ports of Koper and Trieste for chosen vessels $(€)$

(Source: Author's own data; Jurjević et al., 2016; modified)

\begin{tabular}{llllll} 
VESSEL & SPLIT & RIJEKA & PLOČE & KOPER & TRIESTE \\
\hline $\mathbf{1}$ & $7,866.67$ & $7,010.27$ & $8,441.85$ & $5,051.00$ & $4,336.00$ \\
\hline $\mathbf{2}$ & $31,438.35$ & $25,929.08$ & $41,314.50$ & $15,897.00$ & $14,550.00$ \\
\hline $\mathbf{3 *}$ & $67,724.29$ & $63,858.52$ & $79,368.14$ & $67,071.00$ & $41,160.00$
\end{tabular}

* comparison not relevant due to modification in the specifications of the third vessel

\section{THE COMPETITIVENESS OF PORT TARIFFS IN THE NORTH PORT OF SPLIT AND POTENTIAL DEVELOPMENT GUIDELINES}

With the current tariff system and pricing mechanism, the Port of Split and the Split Port Authority, the managing body of the port, are in subordinate position to their Rijeka counterparts. The pricing policy in the Port of Rijeka, imposing the lowest charges as demonstrated in this analysis, can be explained by the port's favorable geostrategic position in the north Adriatic and the vicinity of all the main corridors in the area, the PanEuropean Corridor Vb, the Mediterranean Corridor, the BalticAdriatic Corridor, as well as of the national road and railway connections, especially with Zagreb, and railway connection to Serbia, serving as gateways to northern and eastern European markets. The port's management has also obviously recognized how these advantages can be used and further exploited with the proper pricing policy. The highest price in the Port of Ploče can be substantiated with the general characteristics of the port like the size of the port area, terminal capacity with cargo handling equipment, favorable maximum allowed draft, and other advantages like its geographical position often referred to as the southern gate of the Pan-European Corridor Vc and orientation on vessels carrying bulk. In addition, only the Port of Ploče could "possibly" accommodate the bulk carrier unloading coal, having the draft of $15 \mathrm{~m}$, considered in this analysis only for the purpose of calculation of port charges.

The Port of Split should focus on the acquisition of cargoes convenient considering its natural position, the current state of its infrastructure and superstructure, current and potential new markets, bearing in mind that the Port of Split (North Port) with accompanying basins realizes the total annual turnover of 3.2 million tons and is ranked second in Croatia (Ministry of the Sea, 2017). This result deserves respect and support from the competent institutions. Competitive advantage can only be realized if charges for vessels and cargo owner imposed by the port authority and its concessionaires are modified and made cost-effective both for the port and port users. The discrepancy is mainly seen in towage, port charges and the high share of light dues (these three charges combined account for almost $75 \%$ of the total price), which is a crucial problem in all Croatian ports. Port tariff modifications are intended to create a policy which would attract more general and bulk cargo by offering lower rates for vessels, bearing in mind the steadily increasing container transportation over the last couple of years (Luka d.d., 2016). Incorporating rebates and discounts for vessels performing cargo activities immediately after berthing and granting benefits in the form of extended period of storage time in warehouses is hugely important. The modernization of existing road and railway connectivity is crucial for the port to be able to provide a reliable intermodal connection. The tendency to deepen the port basin to make it suitable for accommodating vessels with the draft of up to 12 meters, has to be supported by the decision to modify the port tariff to make it favorable for all participants in the transport chain.

An increase in the freight transportation volume in the Port of Split is recommended to be realized by complying with EU development strategies pertaining to environmental protection and sustainability. Considering its unfavorable market position and geographic location, outdated infrastructure, especially in the segment of railway connections and limited space for potential expansion, the port is recommended to be developed on the principles of sustainability and introduction of environmentally friendly technologies focusing on the reduction of air pollution, noise and other segments of external costs. The absence of increment in cargo turnover and unfavorable economic conditions in Croatia and its surroundings have to be overcome by strategic orientation on earning the status of an eco-friendly port, which is of outmost importance for the North Port of Split. Competitiveness could be improved by introducing stimulating tariffs for eco-friendly vessels, lower than the minimum price or floor limit, which would be compensated by the increased volume of overall vessel ports of call and activity. This environmental discount would be granted for the utilization of alternative fuels reducing air pollution (e.g. LNG, batteries), scrubbers for the reduction of harmful emissions, ballast water treatment technologies or noise reduction, and calculated on the total price of the port tariff. All profit generated from 
increased turnover of 'green' vessels would be reinvested in the introduction of new technologies into the port, like control of emissions responsive to changes in the composition of air, noise levels and water quality, the implementation of "cold ironing", technology based on onshore power supply and shore hookups allowing vessels to connect to the local power supply network, investment in port mechanization using alternative fuels or the installation of liquefied natural gas (LNG) facilities to supply ships in the North Port. Special attention is recommended to be paid to air pollution and emissions, and the introduction of emissions related discount, as an incentive to use cleaner technologies, for vessels that perform better than required by the International Maritime Organization (IMO) emissions standard Environmental Ship Index (ESI), or to participation in environmental protection programs like the Green Award certificate program. This program rewards high safety and environmental standards in shipping, making ship operation more economically attractive, and is held in high regard in important European ports like Hamburg and Rotterdam (Green Award, 2009) which offer a considerable reduction on port charges for vessels holding the certificate. The introduction of this incentive and its program, intended to reduce the overall port tariff, should decrease costs for vessels, increase the number of vessels calling at the North Port of Split, strengthen the port's market position as an eco-friendly port and increase its competitiveness.

Simultaneously, tariffs for cruisers could increase. High external costs of cruising justify this approach (Slišković et al., 2017). This additional cost should fall at the expense of passengers. The current fee per passenger in transit on a cruiser is $€ 0.91$, and the proposed fee should increase to e.g., $€ 1.91$, with the difference of $1 €$ being included in the price of travel on a cruise liner. The average revenue would amount to approximately $€ 1200-1500$ per cruiser, or close to $€ 300,000$ annually for 237 cruisers calling in the Port of Split in 2017 (Split Port Authority, 2017). This revenue would compensate for ecodiscounts granted to cargo vessels, with the above-mentioned revenue of approximately $€ 300,000$ being equivalent to 10 freight vessels free of charge, 20 vessels with $50 \%$ discount, 40 vessels with $25 \%$ discount or 50 vessels with $20 \%$ discount given the average tariff price of $€ 30,000$. It would result in the arrival of 50 additional vessels, one per week, with the discount of $20 \%$ on the total tariff price, with the potential for further increment in the number of vessels calling at the North Port of Split. In this way, the Port of Split wouldn't deny entry to cruisers, cruisers would not be burdened with additional expenses, the demand would remain the same knowing that the cruising passenger and vessel flows are created by cruise lines based on different factors on the market, taking into account passenger demand and attractiveness of the destination, and the Port of Split would strive to increase and improve freight transportation with proper development as indicated in the Transportation Development Strategy of the Republic of Croatia 2017- 2030 (2017).

The analysis presented in this paper and the analysis provided by Jurjević et al. (2016) indicate that there is a large discrepancy between light dues in Croatian ports and the ports of Koper and Trieste. In spite of the fact that cargo flows and selection of a specific port depend on a variety of market conditions, it is crucial for the Republic of Croatia to lower the light dues for cargo vessels engaging in commercial activities in the North Port, to increase overall competitiveness, especially in the segment of port tariffs, and attract additional cargo.

\section{CONCLUSION}

The amount of port charges can be considered to be an encumbrance for business activities in ports, decisive for the level of competitiveness of individual ports and the overall port system. Determining the optimum port tariff level in the North Port of Split is a sensitive issue, especially since it requires the establishment of an equilibrium between maintaining competitiveness and providing the necessary resources. The potential of the North Port is indisputable and recognized in the Transport Development Strategy of the Republic of Croatia. Consequently the modification of the port tariff imposed by all entities offering services in the port, especially in segments of the overall price burdening the vessel, and aiming to achieve costeffectiveness, is essential both for the port and port users. This would result in an increase in cargo turnover and the number of vessels calling in port, with a special emphasis on the possibility of improving competitiveness by introducing environmental charges in the North Port of Split. The value for money stemming from the provision of services of reliable quality at reasonable expense is important for users. Furthermore, the modernization of existing infrastructure and labeling the port as eco-friendly due to the introduction of green technologies based on the principle of sustainability would increase the port's competitiveness and cargo turnover.

\section{REFERENCES}

Acciaro, M., (2013), A Critical Review of Port Pricing Literature: What Role for Academic Research?, The Asian Journal of Shipping and Logistics, 29 (2), pp. 207228., available at:

https://doi.org/10.1016/j.ajsl.2013.08.005

Berköz, L. and Tekba, D., (1999), The role of ports in the economic development of Turkey, 39th European Congress of the Regional Science Association, August 23-27, Dublin, Ireland.

BIMCO, (2017), Standard Disbursements Account, available at: https://www.bimco. org/, [accessed 23 October 2017.].

Dundović Č., Jugović A. and Žgaljić D., Analysis of Croatian ports in respect to Motorways of the Sea implementation. Proceedings of the 4th International Maritime Science Conference; 2012 June 16-17, Split, Croatia. 
Dundović, Č., Hess S., (2005), Competitiveness of the North Adriatic ports in various cargo flows on selected transport routes, Promet - Traffic \& Transportation, 17(4), pp. 205-216.

Dwarakish, G. S., Salim, A. M., (2015), Review on the Role of Ports in the Development of a Nation, International Conference on Water Resources, Coastal and Ocean Engineering (ICWRCOE 2015), Aquatic Procedia 4, pp. 295 -301., available at: https://doi.org/10.1016/j.aqpro.2015.02.040

Green Award, (2009), Homepage, available at: http://www.greenaward.org/ greenaward/, [accessed 09 November 2017.].

Haralambides, H., (2000). ATENCO: Analysis of the Cost Structure of the TEN-Ports, Report to the European Commission by the Chairman of the Academic Expert Group (AEG) upon project completion, Rotterdam: Erasmus University, available at: http://www.academia.edu/2351509/ATENCO_Analysis_of_the_Cost_Structure_of_ the_TEN-Ports, [accessed 15 October 2017.].

Haralambides, H.E., Verbeke, A., Musso, E. and Bennachio, M., (2001), Port Financing and Pricing in the EU: Theory, Politics and Reality, International Journal of Maritime Economics, 3 (4), pp. 368-386., available at: https://doi.org/10.1057/palgrave.ijme.9100026

International Maritime Organization (IMO), (2017), Overview, available at: https:// business.un.org/en/entities/13, [accessed 18 September 2017.].

Jugović, A., (2012), Sea port management, Rijeka: Sveučilište u Rijeci, Pomorski fakultet u Rijeci.

Jurjević, M., Dundović, Č. and Hess, S., (2016), A model for determining the competitiveness of the ports and traffic routes, Tehnički vjesnik - Technical Gazette, 23(5), pp. 1489-1496., available at: https://doi.org/10.17559/TV-20140709100013

Krčum, M., Plazibat, V. and Jelić Mrčelić, G., (2015), Integration Sea and River Ports - the Challenge of the Croatian Transport System for the 21st Century, Naše more - International Journal of Maritime Science \& Technology "Our Sea", 62 (4), pp. 247255., available at:

https://doi.org/10.17818/NM/2015/4.2

Luka d.d. Split, (2016), Elaborat o gospodarskoj opravdanosti produženja ugovora o prvenstvenoj koncesiji, Luka d.d. Split - izmijenjena verzija, Split, Ekonomsk fakultet Split.

Mchizwa, N.E., (2014), Towards efficient port pricing: a specific look into South African tariff methodology, available at: http://commons.wmu.se/cgi/viewcontent. cgi?article=1465\&context=all_dissertations, [accessed 05 October 2017.]

Meersman, H., Strandenes, S. P. and Van de Voorde, E., (2014), Port pricing, in: Nash, C. (editor) Handbook of Research Methods and Applications in Transport Economics and Policy, Edward Elgar publishing, pp. 329-341, Cheltenham: UK, Northampton: MA, USA.

Meersman, H., Van de Voorde, E. and Vanelslander, T., (2003), Port Pricing: Considerations on Economic Principles and Marginal Costs, European Journal of Transport and Infrastructure Research, 3 (4), 371-386.

Meersman, H., Van de Voorde, E. and Vanelslander, T., (2010), Port competition revisited, Review of Business and Economic Literature, 55 (2), pp. 210-232.
Ministry of the Sea, Transport, and Infrastructure of the Republic of Croatia, (2017), Transport Development Strategy 2017-2030, Zagreb, available at: http://www.mppi. hr/UserDocsImages/MMPI \%20Strategija \%20prometnog \%20razvoja \%20RH \%20 2017.-2030.-final.pdf, [accessed 20 October 2017.].

Poletan Jugović, T., (2006), Criteria preference structure in the optimum transport route choice, Pomorstvo - Scientific Journal of Maritime Research, 20 (2), pp. 47-64., available at: http://hrcak.srce.hr/6898

Split Port Authority, (2017), Dokumenti, available at: http://portsplit.com/luckauprava-split/dokumenti/, [accessed 02 November 2017.].

Split Port Authority, (2017), Kružna putovanja, Najava dolazaka, available at: http:// portsplit.com/kruzna-putovanja/najava-dolazaka/, [accessed 02 November 2017.].

Port of Gothenburg, (2017), Port tariff, available at: https://www.portofgothenburg. com/maritime/port-tariff/, [accessed 23 October 2017.].

Port of Hamburg, (2017), Port fee remains inexpensive, available at: https://www. hafen-hamburg.de/en/news/port-fee-remains-inexpensive-environmentalcomponent-creates-incentive-for-clean-vessels---35465, [accessed 23 October 2017.].

Port of Rotterdam, (2017), Port charges, available at: https://www.portofrotterdam. com/en/shipping/port-dues, [accessed 23 October 2017.]

Port of Vancouver, (2017), ECHO program, available at: https://www.portvancouver. com/environment/water-land-wildlife/marine-mammals/echo-program/, [accessed 23 October 2017.].

Port today, (2017), Russian ports to charge "investment dues" already in 2017, available at: https://port.today/russian-port-investment-dues/, [accessed 23 October 2017.].

Slišković, M., Perić Hadžić, A. and Vukić, L., (2017), Analyzing of Environmental External Costs in Cruise Traffic for Port of Split, The Scientific Journals (SJ) issued by the Maritime University of Szczecin, 50 (122), pp. 91-97., available at: https://doi.org/10.17402/221

Strandenes, S.P. and Marlow, P.B., (2000), Port pricing and competitiveness in short sea shipping, International Journal of Transport Economics, 27 (3), pp. 315-334.

Suykens, F. and Van de Voorde, E., (1998), A Quarter of a Century of Port Management in Europe: objectives and tools, Maritime Policy\& Management, 25(3), pp. 251 - 261., available at:

https://doi.org/10.1080/03088839800000037

United Nations Conference on Trade and Development (UNCTAD), (1975), Port pricing, Report by the UNCTAD Secretariat, New York.

United Nations Conference on Trade and Development (UNCTAD), (1995), Strategic Port pricing, Report by the UNCTAD Secretariat, Geneva.

Valantasis-Kanellos, N. and Song, D. W., (2015), Port Centric Logistics in Concept and Practice, in: Song, D.W. and Panayides, P. (eds.), Maritime Logistics: A Guide to Contemporary Shipping and Port Management (2nded.), London: Kogan Page.

Virlanuta, F. O., Nechita, D. and Oprit-Maftei, C., (2013), Port pricing - strategic component of the integrated management system, Journal of Information, Control and Management Systems, 11(2). 